\title{
PENETAPAN WALI ANAK HASIL PERNIKAHAN PEREMPUAN HAMIL DI LUAR NIKAH (STUDI KASUS DI KANTOR URUSAN AGAMA (KUA) KECAMATAN PALASA KABUPATEN PARIGI MOUTONG)
}

\author{
Rahli Lamatande
}

\begin{abstract}
This study is regarding the Legalization of the Guardianship of Children Born Out of Wedlock (Case Study in Religious Affairs Office (KUA) of Palasa Subdistrict, Parigi Moutong District. Hence, the explanation is based on the problems of (1) What is the guardianship procedure of children born out of wedlock (case study in Religious Affairs Office (KUA) of Palasa Subdistrict, Parigi Moutong District)?, (2) What is the legal framework of guardianship of children born out of wedlock (case study in Religious Affairs Office (KUA) Palasa Subdistrict, Parigi Moutong District)?. This research used qualitative research method through observation and in-depth interview as well as documentation study. The data obtained were analyzed through data reduction technique, data presentation, data verification, and conclusion.

The results of the study show that: (1). The guardianship procedures of children born from marriage in Religious Affairs Office of Palasa Subdistrict are put through in accordance with the procedures of general marriage. The first step was by registering the date of the marriage covenant with ten days grace period, completing the requirement, i.e., in N1 form, and so on. The family guardian of children born out of wedlock could be held if it meets the marriage requirements even though the parents committed adultery. After the requirements of religion and the national principles are fulfilled, nothing could hinder the biological father from becoming the family guardian in the marriage of daughter born out of wedlock. (2). The legal framework of guardianship of the children born out of wedlock in Religious Affairs Office (KUA) of Palasa Subdistrict is based on the regulation of Law Number 1 of 1974 on marriage, the Compilation of Islamic Law (KHI) article 99 and 103.
\end{abstract}

Keywords: Guardianship Determination

\section{PENDAHULUAN}

Sebagaimana diketahui bahwa perkawinan adalah satu jalan yang diberikan Allah Swt kepada umatnya agar terciptanya keturunan dari masingmasing keluarga. Perkawinan menuju salah satu sunnatullah dan jalan manusia menyalurkan nafsu dunianya. Yang pada hakikatnya manusia dibekali rasa tersebut, siapapun, dimanapun dan kapanpun dan dari perkawinan yang sah 
akan tercipta keluarga yang aman dan tentram, sebagaimana firman Allah Swt dalam (Q.S Ar-Ruum ayat [30]: 21)

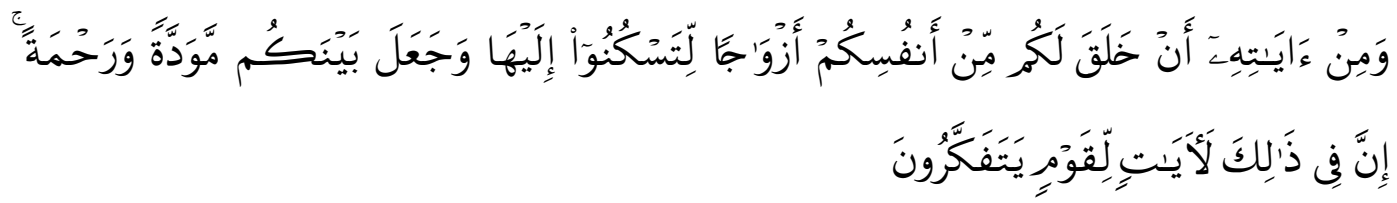

Terjemahnya:

"Dan diantara tanda-tanda kekuasanNya ialah dia menciptakan untukmu isteri-isteri dari jenismu sendiri, supaya kamu cenderung dan merasa tenteram kepadanya, dan dijadikanNya diantaramu rasa kasih dan sayang. Sesungguhnya pada yang demikian itu benar-benar terdapat tanda-tanda bagi kamu yang berfikir."

Ikatan perkawinan adalah suatu ikatan yang sangat kuat antara calon mempelai laki-laki dan calon mempelai perempuan.Kekuatan ikatan perkawinan tersebut yang terikat bukan saja lahiriyahnya saja, melainkan juga terikat batiniyahnya antara suami istri itu dan antara suami istri dengan masing-masing orang tuannya. Akibat hukum adanya ikatan perkawinan yang sah menurut hukum, melahirkan hak-hak dan kewajiban-kewajiban bukan saja antar suami istri itu, melainkan juga dengan pihak lain yaitu adanya hak-hak yang harus diterima anak-anak yang dilahirkannya.

Di antara hak-hak anak yang lahir dari ikatan perkawinan adalah hak perwalian atas anak yang akan melangsungkan ikatan perkawinan, dari hak tersebut Islam mensyariatkan dalam rangka memelihara nasab sebagai cara pandang sah untuk menjaga dan memelihara kemurnian nasab. Terlepas dari beberapa hak yang didapatkan seorang anak, dalam hal perkawinan, nasab merupakan salah satu faktor dari beberapa faktor yang harus dipertimbangkan dalam menjaga keserasian dan kesetaraan kedua calon mempelai. $^{2}$

Adapun yang menjadi rukun perkawinan menurut pasal $14 \mathrm{KHI}$ terdiri dari calon mempelai laki-laki, calon mempelai perempuan, wali nikah, dua orang saksi laki-laki dan adanya ijab qabul. Apabila kelima rukun tersebut terpenuhi,

${ }^{1}$ Departemen Agama RI, Alqur'an dan Terjemahnya (Bandung: Mizan, 2009), 407.

${ }^{2}$ M. Nurul Irfan, Nasab dan Status Anak dakam Hukum Islam (Jakarta: Amzah, 2012), 13-16. 
maka perkawinan adalah sah, akan tetapi jika sebaliknya salah satu dari rukun tersebut tidak terpenuhi maka perkawinan tidak sah adanya. ${ }^{3}$ Dan sebagaimana telah diketahui bahwa Undang-undang tentang perkawinan menurut pasal 1 dan 2 disebutkan bahwa:

Undang-undang Perkawinan adalah ikatan lahir batin antara seorang lakilaki dengan seorang perempuan untuk membentuk rumah tangga yang bahagia dan kekal berdasarkan Ketuhanan Yang maha Esa dan sahnya perkawinan menurut Pasal 2 ayat (1) adalah perkawinan sah apabila dilakukan menurut hukum masing-masing agamanya dan kepercayaannya. ${ }^{4}$

Berdasarkan kedua pasal tersebut jelaslah bahwa Hukum tertulis Negara tentang perkawinan menitik beratkan sah atau tidaknya perkawinan ditentukan pada terpenuhinya rukun perkawinan. Ketika persoalan nasab dikaitkan dengan hukum perkawinan dan kewarisan akan berimplikasi dan pengaruh yuridis yang mutlak harus diperhatikan, yaitu konsep mahram dan konsekuensi memberikan hak perwalian dan waris kepada anak.

Mengingat betapa pentingnya permasalahan nasab ini, maka ajaran Islam sangat menekankan untuk selalu menjaga dan memelihara kemurnian nasab. Dalam rangka inilah Islam mensyariatkan nikah dan larangan keras berbagai bentuk prostitusi dan perzinaan, sebab zina di samping dinilai sebagai perbuatan tercela, keji dan terkutuk, juga dianggap sebagai penyebab kekacauan dan bercampurnya nasab antara yang satu dengan yang lain. ${ }^{5}$

Beberapa kasus seorang perempuan hamil melaksanakan pernikahan meskipun dengan ayah biologis dari calon anak yang dikandungnya dan jika jarak antara perkawinan dengan kelahiran anak belum mencapai waktu 6 bulan, maka secara hukum tertulis maupun hukum Islam bahwa nasab anak yang dilahirkan hanya mempunyai hubungan keperdataan kepada ibunya. Dijelaskan dalam surah al-Ahqaf batas minimal kehamilan dari sebuah perkawinan adalah 6 bulan. Firman Allah Swt dalam (Q.S. Al-ahqaf [46]:15)

\footnotetext{
${ }^{3}$ Ibid.,

${ }^{4}$ Undang-Undang Republik Indonesia Nomor 1 Tahun 1974 tentang Perkawinan.

${ }^{5}$ Irfan,Nasab dan Status, 23-24.
} 


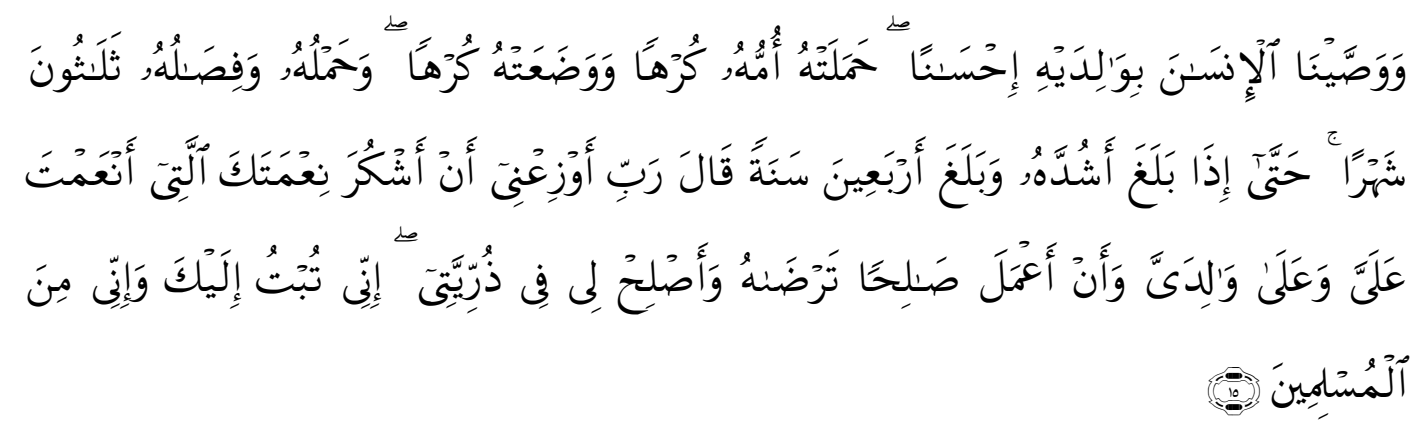

Terjemahnya:

"Kami perintahkan kepada manusia supaya berbuat baik kepada dua orang ibu bapaknya, ibunya mengandungnya dengan susah payah, dan melahirkannya dengan susah payah (pula). Mengandungnya sampai menyapihnya adalah tiga puluh bulan, sehingga apabila dia telah dewasa dan umurnya sampai empat puluh tahun ia berdoa: "Ya Tuhanku, tunjukilah aku untuk mensyukuri nikmat Engkau yang telah Engkau berikan kepadaku dan kepada ibu bapakku dan supaya aku dapat berbuat amal yang saleh yang Engkau ridhai; berilah kebaikan kepadaku dengan (memberi kebaikan) kepada anak cucuku. Sesungguhnya aku bertaubat kepada Engkau dan sesungguhnya aku termasuk orang-orang yang berserah diri". 6

\section{Asbabun Nuzul}

Sementara ulama berpendapat bahwa ayat di atas turun menyangkut Sayyidina Abu Bakar r.a saat usia beliau mencapai 40 tahun. Beliau telah bersahabat dengan Nabi, sejak berumur 18 tahun dan Nabi ketika itu berumur 20 tahun. Mereka sering kali berpergian bersama antara lain dalam perjalanan dagang ke Syam.

Beliau memeluk Islam pada usia 38 tahun di kala Nabi baru beberapa saat mendapat wahyu pertama, dan dua tahun setelah itu Abu Bakar r.a berdo'a dengan kandungan ayat di atas. Sayyidina Abu Bakar memperoleh kehormatan dengan keIslaman ibu bapak dan anak-anaknya. Menurut al-Quthubi tidak seorang sahabat Nabipun yang ayah, ibu, anak-anak lelaki dan perempuan memeluk Islam kecuali Abu Bakar r.a. ${ }^{7}$

\footnotetext{
${ }^{6}$ Departemen Agama RI, Alqur'an, 505.

${ }^{7}$ Sayyid Quthb, Tafsir Fi Zhalali qur'an, jilid 10 (Jakarta : Gema Insani, 2004), 320.
} 
Tafsir

Ayat 15 pada surat Al-Ahqaaf memerintahkan manusia supaya berbuat baik kepada kedua orang tua dengan kebaikan apa saja yang tidak terikat oleh persyaratan tertentu. Pesan ini datang dari pencipta manusia, dan mungkin pesan ini hanya diberikan kepada jenis manusia. Tidak diketahui dengan pasti apakah didunia burung, binatang, serangga dan selainnya ada kewajiban bahwa yang besar mesti mengasihi yang kecil. Namun menurut pengamatan, binatang hanya dibebeni tugas secara naluriah. Yaitu binatang yang besar memelihara binatang yang kecil. Hal ini berlaku pada beberapa jenis binatang saja. Maka, ayat tadi mungkin hanya berlaku bagi manusia.

Redaksi kalimat dan untaian kata-kata pada ayat itu mempersoonifikasikan penderitaan, perjuangan, keletihan dan kepenakan. "Ibunya mengandungnya dengan susah payah, dan melahirkannya dengan susah payah pula." Dia bagaikan orang sakit yang berjuang dengan dirundung kemalangan, memikul beban berat, bernafas dengan susah payah, dan tersengal-sengal. Itulah gambaran saat dia mengandung, terutama menjelang kelahiran anak. Itulah gambar persalinaan, kelahiran, dan aneka kepedihan.

Kedewasaan dicapai pada usia sekitar 30 hinggga 40 tahun. Usia 40 merupakan puncak kematangan dan kedewasaan. Pada usia ini sempurnalah segala potensi dan kekuatan, sehinggga manusia memiliki kesiapan untuk merenung dan berfikir secara tenang dan sempurna. Pada usia ini fitrah yang lurus lagi sehat mengacu pada apa yang ada di balik kehidupan dan sesudahnya, mulai merenungkan tempat kembali dan akhirat.

"Ya Tuhanku, tunjukilah aku untuk mensyukuri nikmat engkau yang telah engkau berikan kepadaku dan kepada ibu bapakku." Inilah seruan qalbu yang mersakan nikmat Tuhannya, yang memandang agung dan besar atas nikmat yang merasakan nikmat Tuhannya, yang memandang agung dan besar atas nikmat yang telah dilimpahkan kepada dirinya dan orang tuanya pada masa lalu, sedang dia merasa usaha untuk mensyukurinya sangatlah minim dan kecil. Hamba tersebut memohon kepada Rabbnya kiranya dia membantu dalam menghimpun segala kekuatannya, "Tunjukanlah kepadaku..." Yakni, agar dia bangkit melaksanakan 
kewajiban bersyukur sehingga kekuatan dan himmahnya tidak terpecah ke dalam berbagai kesibukan yang melupakan kewajiban yang besar ini.

"Serta supaya aku dapat berbuat amal yang saleh yang engkau ridha" Ini adalah permohonan lain. Dia memohon pertolongan agar mendapat taufik untuk beramal saleh sehingga dengan kesempurnaan dan kebaikan amal, dia meraih keridhaan-Nya, lalu Dia ridha kepadanya. "Berikan kebaikan kepadaku dengan (memberi kebaikan) kepada anak cucuku." Inilah permohonan ketiga berupa keinganan hati seorang mukmin agar amal shalehnya sampai kepada keturunannnya dan agar Qalbunya merasa senang jika keturunannya beribadah kepada Allah 'Azza wajalla dan mencari keridhaan-Nya. Do'a itupun merupakan permohonan syafa' at untuk bertaubat dan berserah diri. ${ }^{8}$

Pasal 42 bab IX Undang-undang No.1 tahun 1974 menjelaskan bahwa anak sah adalah anak yang dilahirkan dan atau sebagai akibat perkawinan yang sah. Yang termasuk dalam kategori pasal ini adalah:

1. Anak yang dilahirkan oleh wanita akibat perkawinan yang sah

2. Anak yang dilahirkan oleh wanita di dalam perkawinan sah dengan tenggang waktu 6 bulan antara perkawinan dengan kelahiran anak

3.Anak yang dilahirkan oleh wanita dalam perkawinan yang waktunya kurang dari kebiasaan masa kehamilan tetapi tidak diingkari kelahirannya oleh suami. ${ }^{9}$

Namun, bagaimana dengan praktik yang ada dalam kehidupan nyata bahwa hak perwalian dari seorang anak perempuan yang lahir sebelum batas minimal kehamilan terhitung dari usia perkawinan orang tuanya yang seharusnya dilimpahkan kepada seorang hakim.

Adanya hubungan suami isteri "al-firasy az-zaujiyyah" dinilai sebagai cara untuk menetapkan nasab anak kepada kedua orang tuanya. Dalam kaitan ini, hubungan nasab dapat ditetapkan dengan salah satu dari tiga cara, yaitu perkawinan yang sah atau perkawinan yang fasid, dengan cara ikrar atau pengakuan nasab, dan dengan pembuktian. Cara pertama adalah dengan perkawinan yang sah atau pernikahan yang fasid.

\footnotetext{
${ }^{8}$ Ibid, 320-321.

${ }^{9}$ Undang-Undang Republik Indonesia Nomor 1 Tahun 1974 tentang Perkawinan pasal 42 bab IX.
} 
Perkawinan yang sah atau fasid sebagai sebuah cara untuk menetapkan nasab, cara menetapkannya secara konkrit adalah manakala telah terjadi perkawinan, walaupun berupa kawin fasid atau berupa kawin secara adat masyarakat tertentu, yaitu perkawinan yang telah dianggap terlaksana dengan akad-akad khusus, (seperti nikah di bawah tangan), tanpa didaftarkan pada lembaga perkawinan yang resmi (seperti KUA) hubungan nasab anak-anak yang dilahirkan oleh seorang wanita sebagai istri itu tetap bisa diakui dan ditetapkan. ${ }^{10}$

Kalimat pada Pasal 42 Undang-undang No. 1 tahun 1974 di atas memang benar dan sejalan dengan UUD 1945, HAM dan UU Perlindungan Anak. Namun jika direnungi dan ditelaah secara mendalam, pada dasarnya pernyataan seperti ini ternyata juga tidak tepat. Sebab aturan hukum Islam tentang anak zina yang tidak akan memiliki hubungan nasab dengan ayah biologisnya dan juga tidak bisa menerima nafkah, hak perwalian, dan hak waris dari pewarisnya bukan sebagai hukuman atas anak yang tidak berdosa.

Akan tetapi, sebagai hukuman bagi ayah biologisnya yang biasanya merasa senang dengan lahirnya anak, ayah biologis tidak boleh berbangga atas kelahiran anak tersebut sebab telah melakukan pelanggaran besar berupa perzinaan kepada ibu dari anak tersebut. Sebagai akibat perbuatan yang dilakukan ayah biologis anak yang dilahirkan dari wanita pezinanya, maka ayah biologis tersebut juga dihukum dengan perbuatan hukum untuk tidak memberikan hak perwalian, hak menafkahi anak biologisnya. Hal ini dimaksudkan sebagai konsekuensi logis dari perbuatan zina yang pernah dilakukan. ${ }^{11}$

Problematika yang ada, terkait perwalian dari seorang anak perempuan yang dilahirkan dengan jangka waktu kurang dari 6 bulan perkawinan orang tuanya (kawin hamil). Berdasarkan pasal 42 Undang- undang No.1 Tahun 1974 menyebutkan bahwa anak sah adalah anak yang dilahirkan dalam atau sebagai akibat perkawinan yang sah.

\footnotetext{
${ }^{10}$ Irfan, Nasab dan Status, 123-124.

${ }^{11}$ Ahmad Rofiq, Hukum Islam di Indonesia (Jakarta: Raja Grafindo Persada, 1995), 47.
} 
Aturan dalam hukum Islam dan peraturan hukum positif sangat berbeda, namun karena negara ini adalah negara yang menganut rule of law sehingga apa yang menjadi peraturan harus mengikat warga yang berada dalam negara. Begitu juga terkait problema yang diajukan penulis bahwa perwalian anak hasil kawin hamil oleh ayah biologisnya berdasarkan pasal 42 Undang-undang No.1 Tahun 1974, berbeda dengan aturan dalam Islam yang tidak membolehkan atau memutus nasab anak luar nikah dari ayah biologisnya, kecuali ketika pernikahan orang tuanya dilakukan sebelum batas minimal usia hamil dalam Islam yaitu usia 6 bulan kehamilan. $^{12}$

Aturan yang tertulis di atas, juga Islam mengaturnya, namun memahami dari kedua ketentuan tersebut yang akan menimbulkan pemahaman yang berbeda, dari perbedaan hukum tersebut sehingga Kantor Urusan Agama tempat peristiwa tersebut tidak mengindahkan seorang ayah menjadi wali nikah anak perempuannya yang berkedudukan anak hasil kawin hamil sebelum batas minimal kehamilan, berawal dari kejadian tersebut seorang ayah mengajukan permohonan kepada Pengadilan Agama Kab. Parigi Moutong untuk mendapat penegasan sebagai wali dari perkawinan anak perempuannya yang mempertimbangkan aturan dalam Undang-undang Nomor 1 tahun 1974 pasal 42 disebutkan bahwa "Anak sah adalah anak yang dilahirkan dalam atau sebagai akibat perkawinan yang sah" jo. ${ }^{13}$ Kompilasi Hukum Islam pasal 99 dan pasal 103 daripada aturan dalam Mahkamah Islam Tinggi Republik Indonesia Tahun 1951 yang digunakan sebelum Undang-undang Perkawinan ada.

\section{KAJIAN PUSTAKA}

\section{Pernikahan Dalam Keadaan Wanita Sedang Hamil}

Pernikahan atau yang dalam bahasa Arab disebut pernikahan adalah suatu akad yang mengandung diperbolehkannya wathi' (hubungan badan) dengan lafadz

\footnotetext{
${ }^{12}$ Sunhaji, Hukum Islam: Konsep dan Aplikasinya (Bandung: Pustaka Setia, 2013), 154.

${ }^{13}$ Dokumen Kantor Urusan Agama Kec. Palasa Kab. Parigi Moutong.
} 
nikah atau tazwij atau terjemahannya. ${ }^{14}$ Dalam redaksi lain disebutkan bahwa pernikahan adalah ikatan lahir batin antara seorang pria dengan seorang wanita sebagai suami isteri dengan tujuan membentuk keluarga (rumah tangga) yang bahagia dan kekal berdasarkan Ketuhanan Yang Maha Esa. Demikian adalah yang disebutkan dalam pasal 1 Undang - Undang Pernikahan tahun1974. ${ }^{15}$

Pernikahan disebut sebagai ikatan lahir batin, karena pernikahan bukanlah hal yang dapat dianggap sebagai permainan. Pernikahan memiliki tanggungjawab yang amat besar. Didalamnya terdapat perjanjian antara suami dan isteri yang masing-masing memikul kewajiban dan hak yang harus dijalankan. Substansi yang terkandung didalamnya adalah menaati perintah Allah Swt dan Rasul-Nya, yaitu mendatangkan kemashlahatan baik bagi pelaku pernikahan itu sendiri (suami isteri), anak cucu, kerabat maupun masyarakat. Oleh karena itu, pernikahan bukan hanya kebutuhan internal antara kedua belah pihak, akan tetapi juga faktor eksternal yang melibatkan banyak pihak.

Sebagai suatu perjanjian yang suci ia mengandung pengertian adanya kemauan bebas antara kedua pasangan sehingga tidak ada unsur paksaan. Ia mengikatkan tali perjanjian atas nama Allah Swt bahwa kedua mempelai bermaksud membangun rumah tangga yang sakinah, mawaddah, warahmah. Hal ini sesuai dengan firman Allah Swt dalam (Q.S An-Nisaa' [4]: 21) berikut:

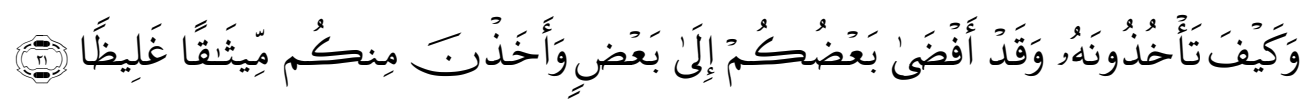

Terjemahnya:

"Bagaimana kamu akan mengambilnya kembali, padahal sebagian kamu telah bercampur dengan yang lain sebagai suami isteri dan mereka (isteri isteri) telah mengambil dari kamu perjanjian yang kuat." 16

Hal tersebut sebagaimana disebutkan dalam Kompilasi Hukum Islam bahwa pernikahan mitsaqan menurut hukum Islam adalah akad yang sangat kuat atau gholiidan untuk mentaati perintah Allah Swt dan melaksanakannya

\footnotetext{
${ }^{14}$ Ahmad Rafi Baihaqi, Membangun Syurga Rumah Tangga, (surabayah: Gita Media Press, 2006), 8

${ }^{15}$ Undang-Undang Republik Indonesia Nomor 1 Tahun 1974 tentang Perkawinan.

${ }^{16}$ Departemen Agama RI, Al Qur'an, 83.
} 
merupakan ibadah. Oleh karena itu, baik pihak laki-laki atau pihak perempuan yang mengikatkan perjanjian itu memiliki kebebasan penuh untuk menyatakan bersedia atau tidak. Perjanjian tersebut dinyatakan dalam ijab qabul yang harus diucapkan dalam satu majelis. ${ }^{17}$ Untuk mewujudkan cita-cita tersebut, pernikahan tidak cukup hanya bersandar dalam ajaran-ajaran Al-Qur'an dan As-Sunnah, namun juga berkaitan dengan hukum suatu negara. Sehingga pernikahan baru dinyatakan sah apabila dilaksanakan sesuai hukum Allah Swt hukum negara. ${ }^{18}$

Pernikahan merupakan salah satu perbuatan yang disyari'atkan Islam untuk mengikat pergaulan antara laki-laki dan perempuan yang bukan mahram sehingga menimbulkan hak dan kewajiban antara keduanya. Islam telah mengatur masalah pernikahan dengan sangat rinci, dan itu ditunjukkan dalam syarat dan ketentuan yang harus dipenuhi dalam pernikahan. Meskipun demikian, lembaga pernikahan tetap menghadapi tantangan, bahkan bisa terancam eksistensinya ketika dihadapkan pada problem sosial tentang masalah kehamilan yang terjadi di luar nikah.

Terjadinya pergaulan yang tidak baik antara lelaki dan wanita karena kehidupan sosial yang tidak terkontrol Problem ini menjadi semakin bertambah rumit ketika dalam kehidupan sosial dewasa ini ternyata kasus ini banyak terjadi di kalangan masyarakat. Kasus ini tidak hanya menyangkut perbuatan zina dari para pelaku dan hukuman hudud atas perbuatannya, melainkan juga menyangkut status dan nasib hidup bayi yang ada dalam kandungannya. ${ }^{19}$ Apabila di persentase, kemungkinan lebih banyak orang yang menikah karena masalah hamil di luar nikah dibandingkan dengan pernikahan yang normal.

Pernikahan dalam keadaan wanita hamil adalah pernikahan yang dilaksanakan karena mempelai wanita pada saat melangsungkan pernikahan tersebut dalam keadaan hamil (pernikahan karena hamil di luar ikatan pernikahan yang sah). Dalam menjawab permasalahan ini, para ulama berbeda pendapat, yaitu:

\footnotetext{
${ }^{17}$ Beni Ahmad Saebani, Fiqh Munakahat 1 (Bandung : Pustaka Setia, 2009), 18.

${ }^{18}$ Undang-Undang Republik Indonesia Nomor 1 Tahun 1974 tentang Perkawinan Pasal 2.

${ }^{19}$ http://publikasiilmiah.ums.ac.id/handle/123456789/2277, Diakses 28 April 2017.
} 
a. Para Ulama Syafi'iyah berpendapat bahwa zina tidak memiliki kewajiban ber iddah, baik wanita tersebut hamil atau tidak. Sama halnya wanita tersebut mempunyai suami atau tidak. Apabila dia mempunyai suami, maka halal bagi suaminya untk menyetubuhinya secara langsung. Dan jika dia tidak mempunyai suami, maka boleh bagi laki-laki yang berzina dengannya atau orang lain untuk menikahinya, baik dia hamil atau tidak. Hanya saja, menyetubuhinya dalam keadaan hamil berhukum makruh sampai dia melahirkan.

b. Jika wanita yang dizinai tidak hamil, maka laki - laki yang berzina dengannya atau laki-laki lain boleh menikahinya, dan dia tidak wajib beriddah. Pendapat ini disepakati di kalangan Madzhab Hanafi. Jika yang menikahinya adalah laki- laki yang berzina dengannya, maka dia boleh menyetubuhinya dan anak adalah milik laki-laki tersebut jika lahir enam bulan setelah pernikahan. Namun jika dilahirkan sebelum enam bulan, maka dia bukan anaknya dan tidak mendapat warisan darinya. $^{20}$

Sedangkan jika wanita yang dizinai hamil, maka menurut Abu Hanifah, dia boleh dinikahi namun tidak boleh disetubuhi sampai melahirkan. Sedangkan Abu Yusuf dan Zafar dari Madzhab Hanafi berpendapat bahwa jika wanita yang berzina hamil, maka dia tidak boleh dinikahi.

c. Wanita yang berzina tidak boleh dinikahi dan dia wajib beriddah dengan waktu yang ditetapkan jika dia tidak hamil, dan dengan melahirkan kandungan jika dia hamil. Jika ia memiliki suami, maka suaminya tidak boleh menyetubuhinya sampai iddahnya habis. Ini adalah pendapat Rabi'ah, Ats Tsauri, Al Auza'i dan Ishaq dari kalangan Madzhab Maliki dan Hanbali. Para ulama Madzhab Hanbali memberikan syarat lain bagi bolehnya menikahi wanita yang berzina yaitu taubat dari zina. ${ }^{21}$

Dalam fikih madzhab Indonesia yang terangkum dalam Kompilasi Hukum Islam, masalah ini dijawab dalam pasal 53 yaitu:

1) Seorang wanita hamil di luar nikah, dapat dikawinkan dengan pria yang menghamilinya.

\footnotetext{
${ }^{20}$ Yahya Abdurrahman Al Khatib, Ahkâm al-Mar'ah al-Hâmil fì asy-Syarî'ah alIslâmiyyah, Terj. Mujahidin Muhayyan, Fikih Wanita Hamil, (Jakarta: Qisthi Press, 2009), 87-88. ${ }^{21}$ Ibid.,
} 
2) Perkawinan dengan wanita hamil yang disebut pada ayat (1) dapat dilangsungkan tanpa menunggu lebih dahulu kelahiran anaknya.

3) Dengan dilangsungkannya perkawinan pada saat wanita hamil, tidak diperlukan perkawinan ulang setelah anak yang dikandung lahir. ${ }^{22}$

Dari keterangan diatas dapat diambil kesimpulan bahwa seorang wanita yang hamil di luar ikatan pernikahan yang sah dapat dinikahkan dengan pria yang menghamilinya tanpa menunggu kelahiran anak dalam kandungannya. Pernikahan tersebut terus berlaku selama tidak ada perceraian sehingga pernikahan yang telah dilaksanakan tersebut tidak perlu diulang kembali meskipun setelah kelahiran anaknya. Dasar yang dipakai pertimbangan oleh Kompilasi Hukum Islam dalam menetapkan pernikahan wanita hamil adalah (Q.S An-Nuur [24]: 3) yang berbunyi:

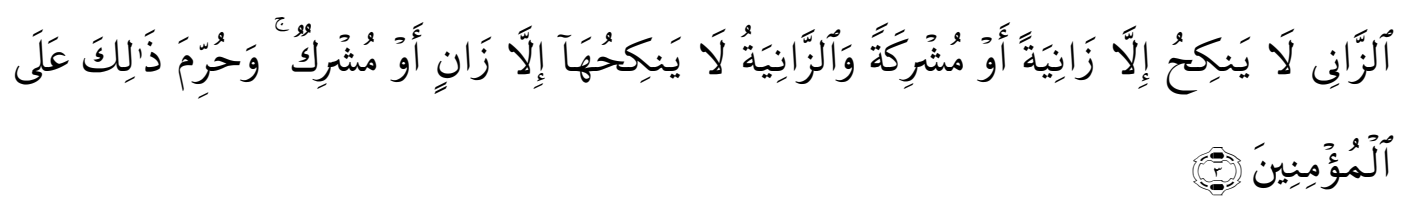

Terjemahnya:

"Laki-laki yang berzina tidak mengawini melainkan perempuan yang berzina, atau perempuan yang musyrik; dan perempuan yang berzina tidak dinikahi melainkan oleh laki-laki yang berzina atau laki-laki musyrik, dan yang demikian itu diharamkan atas oran-orang yang mu'min." 23

Ayat ini diturunkan tatkala orang-orang miskin dari kalangan sahabat Muhajirin berniat untuk mengawini para pelacur orang-orang musyrik, karena mereka orang kaya-kaya. Kaum Muhajirin yang miskin menyayangkan kekayaan yang dimilikinya itu akan dapat menanggung nafkah mereka. Karena itu dikatakan, bahwa pengharaman ini khusus bagi sahabat Muhajirin yang miskin tadi. Tetapi menurut pendapat yang lain mengatakan pengharaman ini bersifat umum dan menyeluruh. ${ }^{24}$

Perbedaan pendapat dalam islam merupakan suatu hal yang biasa terkait dengann pendapat dalam permasalahan ini adalah bahwa ayat tersebut menjelaskan bahwa kebolehan perempuan hamil menikah dengan laki-laki yang

${ }^{22}$ Ibid.,

${ }^{23}$ Departemen Agama RI, Al-qur'an, 351

${ }^{24}$ Imam Jalaluddin Al-Mahalli, Tafsir Jalalain, (Bandung: Sinar Baru Al Gesindo, 2006), 1451-1452. 
menghamilinya adalah suatu pengecualian, sehingga laki- laki yang menghamilinya adalah yang tepat menjadi suaminya. Ayat tersebut juga menerangkan bahwa haram bagi laki-laki mukmin yang baik untuk mengawininya. ${ }^{25}$ Hal tersebut bertujuan untuk menjaga kehormatan laki-laki yang beriman.

\section{Status Anak}

Islam secara tegas telah menyatakan tenang larangan mendekati zina. Larangan tersebut diberlakukan karena efek dari zina adalah mengarah pada pengkaburan keturunan. Termasuk dalam kategori jalan pengkaburan tersebut adalah pengabsahan anak melalui nikah hamil. Hal ini karena tidak semua yang menikahi wanita itu adalah laki-laki yang menghamilinya. Kalaupun yang menikahi itu adalah yang menghamilinya, namun konsepsi. ${ }^{26}$ janin itu terjadi sebelum pernikahannya, sehingga anak tersebut tetap dianggap anak zina. ${ }^{27}$

Dalam konsep Islam, definisi anak sah itu didasarkan pada saat terjadinya konsepsi janin dalam rahim ibunya. Konsepsi tersebut terjadi setelah pernikahan ayah dan ibunya. Dengan demikian dapat dipahami bahwa anak sah adalah anak yang lahir sebagai akibat dari adanya pernikahan. ${ }^{28}$ Para ulama memberikan batasan kelahiran minimal 6 bulan setelah pernikahan. Hal ini merujuk firman Allah Swt dalam (Q.S Luqman, [31] : 14) berikut ini:

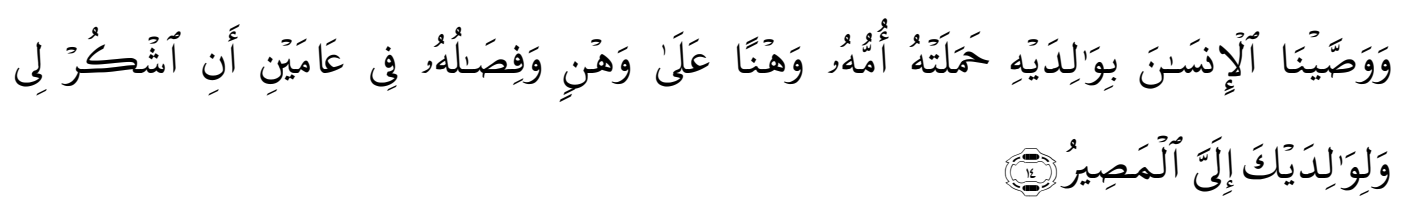

Terjemahnya:

"Dan kami perintahkan kepada manusia (berbuat baik) kepada dua orang ibu-bapanya; ibunya telah mengandungnya dalam keadaan lemah yang bertambah-tambah, dan menyapihnya dalam dua tahun Bersyukurlah

\footnotetext{
${ }^{25}$ Zainuddin Ali, Hukum Perdata Islam Di Indonesia (Jakarta: Sinar Grafika, 2006), 4546.

${ }^{26}$ Masa awal kehamilan yang ditandai oleh pertemuan sel telur dengan sperma yang akan membentuk janin di dalam rahim seorang wanita.

${ }^{27}$ Musthafa Rahman, Anak Luar Nikah Status Dan Implikasi Hukumnya (Jakarta: Atmaja, 2003), 25.

${ }^{28}$ Ibid, $45-54$.
} 
kepadaKu dan kepada dua orang ibu bapakmu, hanya kepada-Kulah kembalimu." 29

Definisi tersebut secara otomatis mengecualikan bahwa semua anak yang lahir diluar pernikahan adalah anak tidak sah (anak zina). Termasuk dalam pengertian ini adalah anak yang dilahirkan dalam pernikahan, namun konsepsi janin terjadi sebelum pernikahan.

Konsep Islam ini berbeda dengan konsep yang ditawarkan oleh Kompilasi Hukum Islam dan Undang - Undang Pernikahan. Dalam KHI pasal 99 disebutkan anak yang sah adalah:

a. Anak yang dilahirkan dalam atau akibat pernikahan yang sah.

b. Hasil pembuahan suami isteri yang sah di luar rahim dan dilahirkan oleh isteri tersebut. $^{30}$

Rumusan tersebut senada dengan rumusan Undang-Undang Pernikahan pasal 42 yang menyatakan bahwa anak yang sah adalah anak yang dilahirkan dalam atau sebagai akibat pernikahan yang sah. Dari kedua rumusan senada tersebut dapat ditarik pengertian bahwa anak sah adalah anak yang lahir "dalam pernikahan" dan anak yang lahir sebagai "akibat pernikahan".

Pengertian pertama (dalam pernikahan) memberikan implikasi bahwa semua anak yang lahir dalam pernikahan, baik proses terjadinya konsepsi janin itu sebelum atau setelah pernikahan dianggap sebagai anak yang sah. Dengan demikian, anak yang dilahirkan dari perbuatan zina dapat dianggap sebagai anak sah apabila kelahirannya terjadi dalam sebuah pernikahan. ${ }^{31}$

Sedangkan pengertian yang kedua (sebagai akibat pernikahan) memberikan pengertian bahwa anak yang sah adalah anak yang memang benarbenar dibenihkan oleh ayah dan ibunya dalam ikatan pernikahan. Anak yang menjadi akibat dari pernikahan adalah anak yang sejak awal konsepsinya sebagai janin dalam kandungan ibunya terjadi setelah ayah dan ibunya terikat pernikahan. Kelahiran anak yang merupakan akibat pernikahan tidak hanya terjadi dalam

\footnotetext{
${ }^{29}$ Departemen Agama RI, Al-qur'an, 413.

${ }^{30}$ KHI pasal 99.

${ }^{31}$ Rahman, Anak Luar Nikah, 54-62.
} 
pernikahan saja, tapi boleh jadi kelahiran itu terjadi setelah adanya pernikahan. ${ }^{32}$

Maksud dari pernyataan kelahiran setelah pernikahan adalah kelahiran yang terjadi pada saat ayah dan ibunya sudah tidak terikat pernikahan. Hal tersebut dikarenakan perceraian keduanya atau ayahnya meninggal namun konsepsi janin terjadi dalam pernikahan tersebut. Konsep ini sejalan dengan konsep yang ditawarkan oleh Islam.

Dalam ajaran Islam, anak sah itu memiliki hubungan keperdataan dengan orang tuanya, baik ayah maupun ibunya. Hubungan tersebut berlanjut sampai kakek atau nenek dari kedua orangtuanya dalam garis lurus ke atas. Akan tetapi bagi anak zina (anak luar nikah) hanya mempunyai hubungan keperdataan pada ibu dan keluarga ibunya. Hal ini sesuai dengan rumusan KHI pasal 100 dan UUP pasal $43 .^{33}$

Dari penjelasan diatas dapat ditarik kesimpulan bahwa pada dasarnya pernikahan sebagaimana yang disebutkan dalam UUP adalah ikatan lahir batin antara seorang pria dan wanita untuk membentuk sebuah keluarga yang tentram berdasarkan aturan agama dan negara. Fenomena yang terjadi saat ini yakni terjadinya pernikahan pasca kehamilan menimbulkan banyak pendapat dikalangan ulama fiqh. Namun Indonesia sebagai negara hukum mengatur masalah - masalah yang berkaitan dengan pernikahan dalam formulasi hukum tersendiri, termasuk di dalamnya masalah nikah hamil dalam UUP dan KHI. Terjadinya pernikahan setelah terjadi kehamilan memberikan dampak terhadap pemberian status kepada anak yang dilahirkan, karena keputusan KHI dan UUP menyatakan bahwa anak yang lahir di luar pernikahan hanya mempunyai hubungan keperdataan pada ibu dan keluarga ibunya.

\footnotetext{
${ }^{32}$ Ibid, 56.

${ }^{33}$ KHI Pasal 100 menyebutkan bahwa anak yang lahir di luar pernikahan hanya mempunyai hubungan nasab dengan ibunya dan keluarga ibunya. dan UUP Pasal 43 (1) menyebutkan anak yang lahir diluar pernikahan hanya mempunyai hubungan perdata dengan ibunya dan keluarga ibunya.
} 
16 | MUSA WA, Vol. 12 No.1 Juni 2020 : 1-29

\section{Pengertian Kawin Hamil dalam Undang-undang}

Pengertian kawin hamil sama halnya dengan Married by Accident secara harfiah terdiri dari tiga kata, yaitu married, by, dan accident. Married adalah kata kerja pasif dari marry yang artinya kawin atau nikah. By artinya dengan atau karena, merupakan kata keterangan, dan accident adalah sebuah kejadian mengejutkan atau kecelakaan. Jadi merried by accident sering diartikan dengan nikah karena kecelakaan, maksudnya karena telah terjadi sebuah kecelakaan berupa kehamilan yang tidak diinginkan, maka seorang terpaksa atau telah terlebih dahulu mempunyai rencana melakukan perkawinan. Dengan demikian married by accident adalah nikah karena kehamilan telah terlanjur terjadi yang pada umumnya tidak direncanakan oleh salah seorang atau kedua pasangan yang mengalaminya. ${ }^{34}$

Telah dijelaskan pula dalam Kompilasi Hukum Islam pada Bab VIII Kawin hamil Pasal 53 ayat (1) bahwa "Seorang wanita hamil di luar nikah, dapat dikawinkan dengan pria yang menghamilinya. Dan juga ayat (2) yaitu Perkawinan dengan wanita hamil yang disebut pada ayat (1) dapat dilangsungkan tanpa menunggu lebih dahulu kelahiran anaknya. Dan sebagai akibat setelah pernikahan kawin hamil tersebut dalam ayat (3) dijelaskan bahwa "Dengan dilangsungkannya perkawinan pada saat wanita hamil, tidak diperlukan perkawinan ulang setelah anak yang dikandung lahir.,35

\section{Perwalian Anak Kawin Hamil}

Keberadaan wali merupakan satu dari lima rukun nikah. Wali sendiri ialah sebutan untuk pihak lelaki dalam keluarga atau lainnya yang bertugas mengawasi keadaan atau kondisi seorang perempuan. Perwalian adalah kewenangan yang diberikan kepada seseorang untuk melakukan sesuatu perbuatan hukum sebagai wakil untuk kepentingan dan atas nama anak yang tidak mempunyai kedua orang

\footnotetext{
${ }^{34}$ Achmad Ichsan, Hukum Perkawinan Bagi Yang Beragama Islam (Jakarta: CV. Muliasari, 1986), 219.

${ }^{35}$ Kompilasi Hukum Islam pada Bab VIII Kawin hamil Pasal 53 ayat (1)
} 
tua, atau orang tua yang masih hidup tidak cakap melakukan perbuatan hukum.

Oleh karena itu, wali adalah orang yang diberikan kewenangan untuk melakukan perbuatan hukum yang di dasarkan pada firman Allah dalam (QS. AlBaqarah [2]: 282) berikut ini:

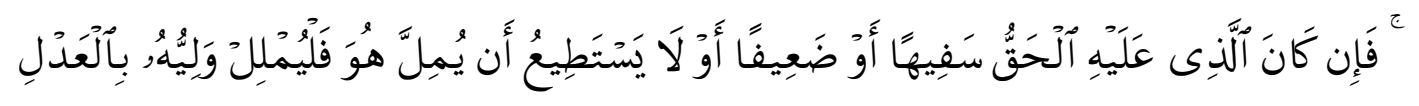

Terjemahnya:

...."Jika yang berutang itu orang yang lemah akalnya atau lemah keadaannya atau dia sendiri tidak mampu mengimlakkan, maka hendaklah walinya mengimlakkan dengan jujur...."36

Sementara definisi perwalian dalam perkawinan adalah suatu kekuasaan atau kewenangan syarei segolongan manusia, yang dilimpahkan kepada orang yang sempurna, karena kekurangan tertentu pada orang yang dikuasai itu, demi kemaslahatannya sendiri. ${ }^{37}$ Wali merupakan salah satu rukun yang harus dipenuhi dalam akad perkawinan, sebagai konsekuensinya adalah perkawinan tidak dianggap sah kecuali adanya wali.

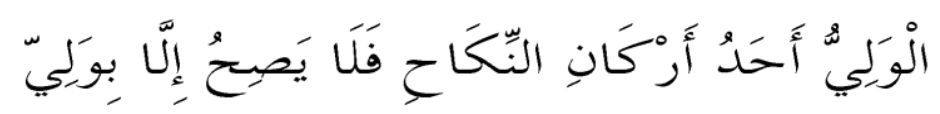

Artinya:

"Wali adalah salah satu rukun nikah, maka nikah tidak sah tanpa wali."

Mayoritas ulama" sepakat tidak menasabkan anak zina kepada ayah biologisnya, kecuali anak-anak yang lahir pada masa Jahiliyyah yang dinasabkan kepada siapa yang mengakuinya, setelah masuk Islam sebagaimana yang dilakukan oleh Sayyidina Umar bin al-Khathab ra. ${ }^{38}$

Sebagaimana mayoritas ulama" telah sepakat atas nasab anak zina bukan kepada ayah biologisnya, maka anak hasil zina yang lahir sebelum batas usia minimal kehamilan yaitu 6 bulan dihitung sejak akad nikah dinasabkan kepada

\footnotetext{
${ }^{36}$ Departemen Agama RI, Alqur'an, 49.

${ }^{37}$ Zainuddin Ali, Hukum Perdata Islam (Jakarta: Sinar Grafika, 2007), 45-46.

${ }^{38}$ Ibnu Rusyd, Bidayah al-Mujtahid wa Nihayah al-Muqtasid juz 2 (Mesir: Mustafa alBabi al- Halabi, 1975), 358.
} 
ibu yang melahirkannya dan kerabat ibunya. Oleh karena itu, penasaban anak zina kepada ibunya mengakibatkan anak tidak mempunyai wali.Sedangkan anak yang tidak mempunyai wali, maka walinya adalah penguasa/ hakim.

Dapat ditarik kesimpulan, laki-laki yang menikahi ibu anak zina tidak bisa menjadi wali nikah bagi anak perempuannya tersebut, tetapi yang menjadi wali nikahnya adalah wali hakim, yaitu pejabat pemerintah dalam hal ini Kementerian Agama atau yang mewakilinya sampai tingkat daerah yakni pejabat Kantor Urusan Agama (KUA).

Dalam fatwa MUI No. 11 Tahun 2013 Tentang Kedudukan Anak Hasil Zina dan Perlakuan Terhadapnya disebutkan bahwa "Anak zina tidak mempunyai hubungan nasab, wali nikah, waris, dan nafaqah dengan laki-laki yang menyebabkan kelahirannya". Dan "Anak zina hanya mempunyai hubungan nasab, waris, dan nafaqah dengan ibunya dan keluarga ibunya". ${ }^{39}$

Karena ayah biologisnya tidak bisa bertindak sebagai wali yang akan menikahkannya, dengan begitu wali akad nikahnya adalah wali hakim. Dalam hal waris, Imam Abu Hanifah, Malik, Asy-Syafiei, dan Ahmad bin Hambal sebagaimana yang dikutip oleh Nurul Irfan berpendapat bahwa anak zina itu mewarisi, dan tidak pula mewariskan dari/kepada "ayah" atau kerabat ayahnya itu. Ia hanya mewarisi dan mewariskan diri kepada pihak ibu dan kerabat ibunya. Hal senada juga disampaikan oleh Ibnu Al-Qayyim, menurutnya anak zina tidak mempunyai hubungan waris-mewarisi dengan ayahnya, dan tidak bisa menuntut nafkah, namun antara keduanya masih terdapat hubungan kemahraman. ${ }^{40}$

Begitulah konsep nasab dalam syarieeat Islam atau hukum Islam, ia merupakan nikmat dan karunia besar yang yidak mungkin dapat ditetapkan atau dibentuk melalui perzinaan yang merupakan larangan Allah Swt. Sebab zina adalah tindak pidana yang pelakunya harus dikenakan sanksi baik rajam, maupun dera seratus kali dan pembuangan. Sedangkan untuk menetapkan nasab

\footnotetext{
${ }^{39}$ Fatwa MUI Nomor 11 tahun 2012 Tentang Anak Hasil Zina dan Perlakuan Terhadapnya.

${ }^{40}$ Nurul Irfan, Nasab dan Status, 114-116.
} 
harus bersih dari tindak pidana dan perbuatan dosa, sebab nasab merupakan karunia Allah Swt yang harus senantiasa dipelihara kemurniannya. ${ }^{41}$

\section{METODE PENELITIAN}

\section{Jenis Penelitian}

Dalam penelitian ini, Peneliti menggunakan penelitian kualitatif. Penelitian ini digunakan karena menyangkut penelitian yang hanya mendeskripsikan fakta empiris dengan kata-kata atau berupa pernyataan lisan tentang wali anak hasil pernikahan perempuan hamil (studi kasus di Kantor Urusan Agama (KUA) Kecamatan Palasa Kabupaten Parigi Moutong). Hal ini sebagaimana dikemukakan oleh Bogdan dan Taylor seperti dikutip oleh Trimo Prabowo, mendefinisikan metode kualitatif adalah sebagai prosedur penelitian yang menghasikan data deskriptif berupa kata-kata tertulis atau lisan dari orang-orang dan perilaku yang dapat diamati menurut mereka. ${ }^{42}$

Sejalan dengan uraian di atas, oleh Miles dan Huberman:

Singkatnya, hal-hal apa yang terdapat dalam analisis kualitatif pertama, data yang muncul berwujud kata-kata dan bukan rangkaian angka. Data itu mungkin telah dikumpulkan dalam aneka macam cara (observasi, wawancara, intisari dokumen, pita rekaman) dan yang biasanya "diproses" kira-kira sebelum siap digunakan (melalui pencatatan, pengetikan, penyuntingan atau alih tulis), tetapi analisis kualitatif tetap menggunakan kata-kata, yang biasanya disusun dalam teks yang diperluas. ${ }^{43}$

Penelitian kualitatif pada prinsipnya merupakan salah satu upaya untuk menemukan teori yang dapat menunjang hasil penelitian dan hal itu dilakukan melalui pendekatan induktif. Dengan pendekatan tersebut data dikumpulkan kemudian dianalisis, diabstraksikan, sehingga muncul teori-teori sebagai

\footnotetext{
${ }^{41}$ Ibid, 121.

${ }^{42}$ Trimo Prabowo, http://.blogspot.com/2017/10/makalah-perbedaan-dan-
} persamaan.html, Diakses 22 Juni 2018

${ }^{43}$ Matthew B. Miles dan A. Michael Huberman, Analisis Data Kualitatif, Buku Tentang Metode-Metode Baru (Jakarta: UI-Press, 1992), 15-16. 
penemuan penelitian kualitatif. ${ }^{44}$ Adapun pertimbangan-pertimbangan yang Peneliti gunakan pada penelitian ini dengan pendekatan kualitatif ini sebagai berikut:

1. Penyesuaian pendekatan kualitatif lebih mudah apabila berhadapan dengan kenyataan ganda.

2. Bersifat langsung antara penelitian dengan informan.

3. Lebih peka dan lebih dapat menyesuaikan diri dengan banyak penajaman pengaruh bersama terhadap pola-pola nilai yang dihadapi. ${ }^{45}$

Berdasarkan pertimbangan teoritis di atas, maka dapat dinyatakan penelitian ini sangat tepat menggunakan pendekatan kualitatif yang fokus prosedurnya ingin mengungkapkan dan menghasilkan data yang sifatnya deskriptif berupa kata-kata mengenai wali anak hasil pernikahan perempuan hamil (studi kasus di Kantor Urusan Agama (KUA) Kecamatan Palasa Kabupaten Parigi Moutong).

\section{HASIL PENELITIAN}

Prosedur Pelaksanaan Wali Anak Hasil Pernikahan Perempuan Hamil di Kantor Urusan Agama (KUA) Kecamatan Palasa

Suatu perkawinan dapat dilangsungkan apabila telah terpenuhinya syarat dan rukunnya, selain terpenuhinya syarat dan rukun perkawinan, dalam Undangundang juga tertulis dengan terpenuhinya syarat administrasi. Meskipun dalam agama hanya terdapat syarat dan rukun yang harus terpenuhi, akan tetapi untuk tujuan kepastian hukum maka harus terpenuhi juga syarat secara administrasi pemerintahan. Pelaksanaan perkawinan dapat dilangsungkan setelah jarak 10 hari sejak pendaftaran di KUA setempat. Terkait perkawinan anak hasil kawin hamil, kepala KUA Kecamatan Palasa, memberikan pendapatnya:

"Tidak ada perbedaan prosedur perkawinan anak hasil kawin hamil, sama prosedurnya dengan perkawinan umumnya yaitu terpenuhinya syarat dan rukun perkawinan. Dan tidak cukup itu saja syarat administrasipun juga menjadi ketentuan sah tidaknya perkawinan menurut negara, maka dari itu apabila ada seseorang mendaftar melakukan perkawinan, syarat dan rukun secara agama dan administrasi harus diteliti dengan detail., ${ }^{46}$

\footnotetext{
${ }^{44}$ Trimo Prabowo, http://.blogspot .com /2017/10/ makalah-perbedaan -dan-persamaan. html, Diakses 22 Juni 2018.

${ }^{45}$ Miles dan Huberman, Analisis, 21

${ }^{46}$ Muhammad Rajab Kepala KUA, “Wawancara”, (Kantor KUA Kecamatan Palasa) tanggal, 1 Agustus 2018.
} 
Hal yang sama diungkapkan oleh bapak Sukirman, selaku Pegawai Pencatat Nikah (PPN) di KUA Kecamatan Palasa Beliau berpendapat bahwa:

"Selama saya menjadi PPN, tidak jarang menangani kasus kawin hamil, akan tetapi ketika keturunannya itu mau melaksanakan perkawinan, pasti akan ditanya detail. Meskipun undang-undang membolehkan bapaknya jadi wali, tapi dari kita juga mencoba mengarahkan pak. Seharusnya bagaimana kalau seperti ini. Dan sama saja prosedur perkawinannya, tidak ada perbedaan". 47

Dari hasil wawancara dengan informan diatas dapat disimpulkan bahwa tidak ada perbedaan prosedur perkawinan antara anak hasil kawin hamil maupun perkawinan pada umumnya. Ketika syarat dan rukun sudah terpenuhi, maka perkawinan dapat dilangsungkan sebagaimana mestinya. Hanya saja sedikit lebih ketelitian ketika perkawinan anak hasil kawin hamil akan dilaksanakan. Sebagaimana penjelasan bapak Ramli sebagai berikut:

"Dulu itu ada perhitungan wali, jadi ketika seseorang akan melangsungkan perkawinan akan diteliti benar masalah perwaliannya, apabila kelahiran anak dengan usia perkawinan orangtua tidak ada 6 bulan, maka wali nya wali hakim. Tapi sekarang sudah tidak ada aturan seperti itu.",48

Aturan perhitungan wali akan berbenturan dengan peraturan Negara dalam Undang-Undang No. 1 Tahun 1974 dalam bab IX tentang Kedudukan Anak pasal 42 yaitu "Anak yang sah adalah anak yang dilahirkan dalam atau sebagai akibat perkawinan yang sah." Tidak ada batasan usia perkawinan dengan lahirnya anak, hanya ketika sudah terjadi perkawinan, maka anak yang dilahirkan akan sah menjadi anak dari perkawinan tersebut, begitu juga berhak atas apa yang menjadi tanggung jawab orangtua, diantaranya hak waris mewarisi, menjadi wali, memberi nafkah dan lainnya.

Wanita yang hamil kemudian melaksanakan perkawinan dengan laki-laki yang menghamilimya secara agama maupun negara tidak ada larangan, sebagaimana tertulis dalam Kompilasi Hukum Islam pasal 53 ayat (1) yang berbunyi "seorang wanita hamil diluar nikah, dapat dikawinkan dengan pria

\footnotetext{
${ }^{47}$ Sukirman, PPN, “Wawancara”, (Kantor KUA Kecamatan Palasa) tanggal, 1 Agustus 2018.

${ }^{48}$ Ramli Pegawai KUA, “Wawancara”, (Kantor KUA Kecamatan Palasa) tanggal, 6 Agustus 2018.
} 
yang menghamilinya" dan juga disebutkan pada ayat berikutnya bahwa "perkawinan dengan wanita hamil yang disebut pada ayat (1) dapat di langsungkan tanpa menunggu lebih dulu kelahiran anaknya."

Dengan demikian demi menjaga kemaslahatan hukum Islam dan juga hukum negara tidak ada perbedaan dalam larangan wanita hamil menikah. Hanya saja sedikit perbedaan dalam ulama' mazhab dalam pendapatnya terkait status anak yang dilahirkan. Kebanyakan ulama' berpendapat bahwa apabila anak lahir dengan jarak perkawinan orangtua yang kurang dari 6 bulan, maka jika anak yang dilahirkan berjenis kelamin perempuan, hanya mempunyai hubungan keperdataan dengan keluarga ibunya, adapun ketika telah dewasa dan akan melaksanakan perkawinan, yang berhak menjadi wali adalah wali hakim.

Dari penjelasan bapak Ramli menjelaskan pendapatnya:

"Kalau kita melihat hukum Islam atau hukum positif ya berbeda, jelas itu. Tapi kita ini kan hidup di negara hukum bukan Negara islam, jadi yang menjadi acuan dalam bertindak ya aturan yang sudah ada di negara ini" 49

Dari penjelasan bapak Ramli dapat dikatakan bahwa karena berada dalam negara hukum, maka aturan yang dipakai adalah aturan negara, dan negara membuat aturan tersebut bukan tidak ada karena sebab tujuan, akan tetapi juga demi kemaslahatan masyarakat. Meskipun tidak sedikit yang menolak aturan yang berlaku, tetapi aturan tetaplah aturan sebagai tolak ukur rujukan suatu masalah. Bapak Surahman, selaku tokoh agama di Kecamatan Palasa, juga memberikan pendapatnya:

"selama saya di mintai bantuan menjadi wali dari mempelai perempuan, sebelumnya saya pasti bertanya asal usul anaknya, dan kalau anaknya itu dari hasil zina/luar nikah. Saya akan minta maaf mundur, saya tidak bias menjadi wali tetapi hukum Islam mengatakan walinya bukan dari nasab tetapi wali hakim". 50

Dapat disimpulkan pendapat bapak Surahman, bahwa aturan Negara memang sebuah aturan, akan tetapi untuk masalah yang menurut agama tidak bisa

\footnotetext{
${ }^{49}$ Ramli Pegawai KUA, “Wawancara”, (Kantor KUA Kecamatan Palasa) tanggal, 6 Agustus 2018.

${ }^{50}$ Surahman, Tokoh Agama, “Wawancara”, (Rumah Warga) tanggal, 8 Agustus 2018.
} 
dilakukan, maka dengan hati nurani pribadi, tidaklah patut dilakukan. Untuk menjaga segala yang kemungkinan tidak tahu suatu saat nanti.

Kembali dari kontekstual hukum islam, negara Indonesia adalah negara hukum bukan negara Islam, dan yang sudah tertulis dalam aturan Negara bahwa anak sah adalah anak yang lahir sebagai akibat perkawinan yang sah. Dan juga tercatat di pejabat pencatat nikah atau KUA. Maka tidak ada halangan ketika anak tersebut telah dewasa dan melangsungkan perkawinan, ayahnya bisa menjadi wali dari perkawinan anaknya.

Atas pertimbangan tersebut tidak ada keraguan seseorang wanita yang hamil melangsungkan perkawinan dengan laki- laki yang menghamilinya. Dengan tujuan menjaga aib keluarga. Yang menjadi acuan dalam penetapan wali anak hasil kawin hamil adalah ketika orangtua mempunyai akta nikah atau buku nikah, sehingga apabila buku nikah ada, maka anak tersebut adalah anak sah dari kedua orang tuanya, dengan bukti adanya buku nikah orang tua.I

\section{Dasar Hukum Pelaksanaan Wali Anak Hasil Pernikahan Perempuan Hamil di Kantor Urusan Agama (KUA) Kecamatan Palasa}

Sebagai dasar pertimbangan pejabat KUA Kecamatan Palasa yaitu perundang-undangan negara. Pada dasarnya Kantor Urusan Agama tidak mengizinkan wali nasab dalam menjadi wali hasil kawin hamil yang jarak usia kelahiran dan perkawinan orang tua belum mencapai 6 bulan. Dikarenakan jelas dalam hukum Islam terdapat aturan jarak minimal usia kandungan yaitu 6 bulan atau 24 minggu, perkawinannya sah akan tetapi ketika anak yang dilahirkan berjenis kelamin perempuan maka hanya dapat dinasabkan kepada keluarga ibunya, bukan keluarga ayah biologisnya. Akan tetapi karena dari pihak wali nasab berpendapat adanya dua pendapat dalam aturan negara yang tidak sama, maka pihak wali meminta permohonan fatwa yang diperantara KUA Kecamatan Palasa. Bapak Moh Lamadau memberikan pendapatnya sebagai berikut:

"gini ya Pak, awalnya legislasi itu juga tidak kami izinkan, karena aturan agama jelas tidak membolehkan, tetapi dari pihak keluarga meminta fatwa 
dari Pengadilan Agama untuk memperjelas aturan mana yang digunakan, akhirnya kami ya mengikuti perintah atasan.",51

Begitu juga bapak Muhamad Rajab, memberikan pendapatnya:

"Waktu 10 hari pendaftaran itu, saya memeriksa detail asal usul anak, kan jelas dalam akta kelahiran dengan akta nikah, jarak kelahiran anak kurang dari 6 bulan. Kalo orangnya berpendidikan biasa pasti mau wali nya wali hakim, tetapi berbeda dengan orang yang berpendidikan tinggi, pasti akan berpendapat dengan ilmu yang dipelajarinya, demi menutupi aib keluarga juga." 52

Dari kedua pendapat diatas dapat disimpulkan bahwa yang menjadi dasar legislasi wali anak kawin hamil yaitu perundang-undangan negara. Dalam Kompilasi Hukum Islam bab VIII pasal 53 tentang kawin hamil dalam ayat 1 dijelaskan "seorang wanita hamil di luar nikah, dapat dikawinkan dengan pria yang menghamilinya." Dengan rujukan QS. Al-Nur ayat [24]: 3 yang berbunyi:

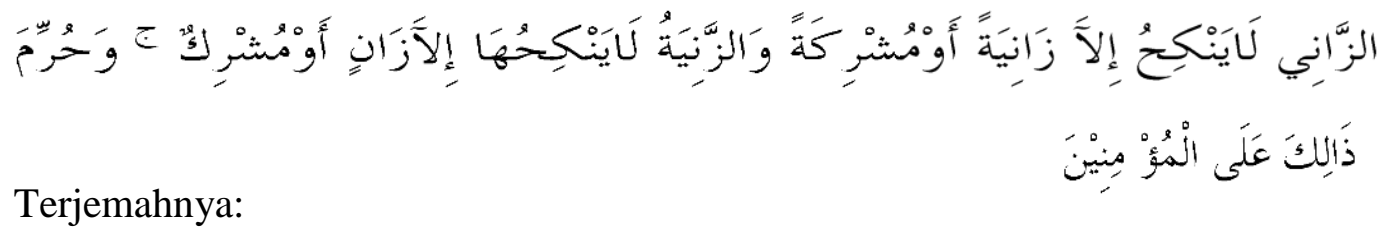

Terjemahnya:

"Laki-laki yang berzina tidak mengawini melainkan perempuan yang berzina, atau perempuan yang musyrik, dan perempuan berzina tidak dikawini melainkan oleh laki-laki yang berzina atau laki-laki yang musyrik, dan yang demikian itu diharamkan atas orang-orang yang mukmin."

Dan juga dalam Undang-Undang Nomor 1 Tahun 1974 tentang perkawinan dalam bab IX tentang kedudukan anak pasal 42 yang berbunyi "anak sah adalah anak yang dilahirkan dalam atau sebagai akibat perkawinan yang sah". Dan dalam bab 1 Pasal 2 ayat (1) yang berbunyi "perkawinan adalah sah, apabila dilakukan menurut hukum masing-masing agamanya dan kepercayaannya itu" dilanjutkan ayat (2) yaitu "tiap-tiap perkawinan dicatat menurut peraturan perundang-undangan yang berlaku”.

\footnotetext{
${ }^{51}$ Moh Lamadau, Pegawai KUA, “Wawancara”, (Kantor KUA Kecamatan Palasa) tanggal, 10 Agustus 2018.

${ }^{52}$ Muhamad Rajab, Kepala KUA, “Wawancara”, (Kantor KUA Kecamatan Palasa) tanggal, 10 Agustus 2018.
} 
Dari aturan yang disebut diataslah pertimbangan legislasi wali anak kawin hamil di KUA Kecamatan Palasa dilaksanakan. Dan juga aturan pendukung lainnya yang dapat dijadikan rujukan atas dasar legislasi tersebut. Karena Undang-Undang perkawinan tidak menyebutkan kawin hamil dan hanya dalam Kompilasi Hukum Islam yang menyebutkan terkait kawin hamil.

Setelah pertimbangan tersebut diatas, syarat pelaksanaan legislasi wali kawin hamil ini sebagaimana dijelaskan Ibu Misbah sebagai berikut:

"Syarat pelaksanaan legislasi tersebut terutama terkait akta nikah orang tua dan akta kelahiran anak itu sendiri, apabila cocok perkawinan dapat dilangsungkan., 53

Sepadan dengan pendapat bapak Sukirman, selaku PPN, ia mengatakan bahwa:

"Yang penting akta nikah sama akta kelahiran cocok nama orang tua dan anaknya, perkawinan dapat dilangsungkan pak, kalo masalah lainnya itu sebagai penunjang saja."

Kedua pendapat menjelaskan bahwa syarat pokok atau utama melangsungkan perkawinan hasil kawin hamil yaitu kecocokan akta nikah dan akta kelahiran anak, karena ketika perkawinan orang tua telah tercatat maka anak yang dilahirkan tersebut secara otomatis adalah anak sah kedua orangtua tersebut. Dari ketentuan Undang-undang No. 1 Tahun 1945 tentang perkawinan tersebut pelaksanaan legislasi oleh lembaga dibawah kewenangan Kementrian agama yaitu KUA khususnya KUA Kecamatan Palasa. tersebut dapat melangsungkan perkawinan anak hasil dari perkawinan orangtua yang didahului kehamilan sebagai wali nasab calon pengantin perempuannya.

Adapun selain syarat utama pelaksanaan perkawinan anak hasil kawin hasil tersebut yakni akta nikah dan akta kelahiran, juga terdapat syarat yang harus dipenuhi ketika perkawinan, yaitu:

a. Syarat calon suami: Islam, terang laki-laki (bukan banci), tidak dipaksa, tidak beristeri empat orang, bukan mahram calon isteri, tidak

\footnotetext{
${ }^{53}$ Misbah, Pegawai KUA, “Wawancara”, (Kantor KUA Kecamatan Palasa) tanggal, 13 Agustus 2018. 2018 .

${ }^{54}$ Sukirman, PPN, “Wawancara”, (Kantor KUA Kecamatan Palasa) tanggal, 13 Agustus
} 
punya isteri yang haram dimadu dengan calon isteri, mengetahui calon isteri tidak haram dinikahi dan tidak sedang ihram haji atau umrah.

b. Syarat calon isteri: Islam, terang wanita (bukan banci), telah memberi izin kepada wali untuk menikahkannya, tidak bersuami dan tidak dalam iddah, bukan mahram calon suami, sudah pernah dilihat calon suami, dan tidak dalam ihram dan umrah. c. Syarat wali: Islam, baligh, berakal, tidak dipkasa, terang laki- lakinya, adil (bukan fasik), tidak sedang ihram haji atau umrah, tidak dicabut haknya dalam menguasai harta bendanya oleh pemerintah (mahjur bissafah), dan tidak rusak pikirannya karean tua atau sebagainya.

d. Syarat saksi: Islam, laki-laki, baligh, berakal, adil, mendengar (tidak tuli), melihat (tidak buta), tidak bisu, tidak pelupa (mughaffal). menjaga harga diri menjaga muru'ah), mengerti maksud ijab kabul, tidak merangkap menjadi wali. e. Ijab kabul: ijab dari wali perempuan seperti : "hai fulan bin.....saya nikahkan fulanah anak saya dengan engkau, dengan mas kawin (mahar)....Kabul: dari calon mempelai laki-laki seperti saya terima nikahnya fulanah binti....dengan mas kawin (mahar). ${ }^{55}$

Terkait pertimbangan yang dijelaskan diatas, seringkali juga terdapat pertimbangan subjektif dari pejabat terkait pelaksanaan legislasi wali anak hasil kawin hamil di Kec. Palasa ini, dijelaskan oleh bapak Muhamad Rajab dalam pendapatnya:

"Terkait pertimbangan subjektif itu hanya kasuistik Pak, misalnya bagi orang-orang yang berpendidikan tinggi, anak seorang yang punya pangkat, orang yang berani melapor atau meminta pertanggungjawaban pihak yang berwenang dalam masalah terkait ini mengajukan ke Pengadilan Agama, kalau menyangkut pertimbangan subjektifnya saya rasa sebab-sebab seperti itu." 56

Dalam penjelasan beliau tentang tujuan dan latar belakang legislasi wali nikah anak hasil kawin hamil ini dikembalikan pada peraturan yang ada, mulai dari pasal 53 KHI yang mengizinkan wanita hamil menikah, dan

\footnotetext{
${ }^{55}$ Dokumen KUA Kecamatan Palasa 2018.

${ }^{56}$ Muhammad Rajab Kepala KUA, "Wawancara”, (Kantor KUA Kecamatan Palasa) tanggal, 15 Agustus 2018.
} 
perkawinan yang sudah sesuai dengan pasal 2 ayat (1) dan (2) yaitu perkawinan yang sah, maka secara langsung nasab juga akan sah menjadi wali ketika anak yang dilahirkan perempuan dan akan melangsungkan perkawinan. Begitu juga hukum timbal balik antara anak dan orangtua seperti halnya hak waris mewarisi antara keduanya, hak wali, hak menafkahi dan lain sebagainya. Masuk dalam tujuan legislasi tersebut hanya bertujuan demi kemaslahatan umum, karena adanya aturan perundang-undangan tujuan utama juga kemaslahatan umum. Aturan yang dibuat bertujuan agar setiap warga negara dapat terlindungi dengan adanya aturan tersebut dan hak hak warga negara dapat terealisasi dengan baik dalam kehidupan berbangsa dan bernegara.

\section{PENUTUP}

Penulis mengemukakan beberapa kesimpulan dari uraian-uraian terdahulu sehingga secara sepintas dapat diketahui gambaran serta menyeluruh dari pembahasan, dengan kesimpulan sebagai berikut :

1. Prosedur pelaksanaan wali anak hasil pernikahan perempuan hamil Kantor Urusan Agama (KUA) Kecamatan Palasa dilaksanakan sebagaimana tatacara dan prosedur pada perkawinan umumnya. Langkah pertama dengan mendaftarkan tanggal akad nikah dengan tenggang waktu 10 hari, melengkapi persyaratan yang sudah diatur, yaitu berbentuk N1 dan seterusnya. Wali nasab hasil perkawinan hamil dapat dilangsungkan apabila telah memenuhi syarat- syarat, rukun-rukun nikah meskipun perbuatan zina yang dilakukan kedua orang tuanya adalah perbuatan zina. Ketika persyaratan dan rukun secara agama dan hokum negara sudah terpenuhi, maka tidak ada halangan ayah biologisnya menghendaki menjadi wali nasab diperkawinan anak perempuan yang lahir dari hasil kawin hamil.

2. Dasar hukum pelaksanaan wali anak hasil pernikahan perempuan hamil di Kantor Urusan Agama (KUA) Kecamatan Palasa yaitu Penetapan berdasarkan peraturan dalam Undang-Undang No. 1 (KHI) pasal 99 dan 
pasal 103. Yang menjadi dasar hukum pelaksanaan wali nasab anak hasil kawin hamil ini tertera dalam Undang-undang dan juga Kompilasi Hukum Islam, berawal dari diperbolehkan wanita hamil menikah dengan ketentuan laki-laki yang menghamilinya yang menjadi mempelai laki-laki tertera pada Kompilasi Hukum Islam BAB VIII pasal53 tentang kawin hamil, dan sebagai akibat dari perkawinan yang sah menurut UndangUndang No. 1 Tahun 1974 pasal 2 ayat (1) dan (2) yang menyatakan perkawinan sah adalah perkawinan yang dilaksanakan menurut agama masing-masing dan atau kepercayaaannya, pada pasal berikutnya menjelaskan bahwa disamping perkawinan dilaksanakan menurut agama masing-masing akantetapi belum diakui negara ketika perkawinan tersebut tidak dicatatkan oleh pegawai pencatat nikah dan menurut aturan yang berlaku. Dari hasil perkawinan yang sah tersebut ketika anak yang dikandung keluar, maka akan sah pula status anak tersebut menjadi anak sah sebagaimana dalam Undang-undang No. 1 Tahun 1974 pasal 42 jo Kompilasi Hukum Islam pasal 99.

\section{DAFTAR PUSTAKA}

Al Khatib, Yahya Abdurrahman. Ahkâm al-Mar'ah al-Hâmil fî asy-Syarî'ah alIslâmiyyah, Terj. Mujahidin Muhayyan, Fikih Wanita Hamil. Jakarta: Qisthi Press, 2009

Ali, Zainuddin. Hukum Perdata Islam Di Indonesia.J akarta: Sinar Grafika, 2006

Al-Mahalli, Imam Jalaluddin. Tafsir Jalalain. Bandung: Sinar Baru Al Gesindo, 2006

Baihaqi, Ahmad Rafi. Membangun Syurga Rumah Tangga. Surabayah: Gita Media Press, 2006

Departemen Agama RI. Alqur'an dan Terjemahnya. Bandung: Mizan, 2009.

Fatwa MUI Nomor 11 tahun 2012 Tentang Anak Hasil Zina dan Perlakuan Terhadapnya.

http://publikasiilmiah.ums.ac.id/handle/123456789/2277, Diakses 28 April 2017. 
Ichsan, Achmad. Hukum Perkawinan Bagi Yang Beragama Islam. Jakarta: CV. Muliasari, 1986

Irfan, M. Nurul. Nasab dan Status Anak dakam Hukum Islam. Jakarta: Amzah, 2012.

Miles, Matthew B dan A. Michael Huberman, Analisis Data Kualitatif, Buku Tentang Metode-Metode Baru. Jakarta: UI-Press, 1992

Prabowo, Trimo. http:// .blogspot .com /2017/10/ makalah- perbedaan -danpersamaan. html, Diakses 22 Juni 2018.

Prabowo, Trimo. http://.blogspot.com/2017/10/makalah-perbedaan-danpersamaan.html, Diakses 22 Juni 2018

Quthb, Sayyid. Tafsir Fi Zhalali qur'an, jilid 10. Jakarta : Gema Insani, 2004

Rahman, Musthafa. Anak Luar Nikah Status Dan Implikasi Hukumnya. Jakarta: Atmaja, 2003

Rofiq, Ahmad. Hukum Islam di Indonesia. Jakarta: Raja Grafindo Persada, 1995

Rusyd, Ibnu. Bidayah al-Mujtahid wa Nihayah al-Muqtasid juz 2. Mesir: Mustafa al-Babi al- Halabi, 1975

Saebani, Beni Ahmad. Fiqh Munakahat 1. Bandung : Pustaka Setia, 2009

Sunhaji. Hukum Islam: Konsep dan Aplikasinya. Bandung: Pustaka Setia, 2013

Undang-Undang Republik Indonesia Nomor 1 Tahun 1974 tentang Perkawinan. 